\title{
Creative Crisis? Performing Artists in Vienna's Live Music Scene in the Age of COVID-19
}

\author{
Magdalena Fürnkranz \\ University of Music and Performing Arts Vienna \\ fuernkranz@mdw.ac.at
}

\begin{abstract}
Cultural workers are affected more than many other working populations by the COVID19 pandemic. Especially, live music as an antidote to crisis highlights the benefits of performing art in times of isolation; a practice that risks normalizing the idea that musicians are performing for free. This article discusses the intersection of live music with social and cultural issues, focusing on Vienna's popular music scene. I begin my inquiry with an insight into the area of live music research, based on the works of Philip Auslander and Simon Frith. Throughout the text, I turn a critical eye to the broad impacts of the pandemic on music-making, the ways in which the potentials of emerging communities are leading to changed forms of appreciation, and emphasize the "sense of community" (Auslander) by way of three case studies. Ultimately, I aim to shed light on the strategies through which musicians deal with the crisis.
\end{abstract}

KEYWORDS: live music research, COVID-19 pandemic, Vienna, performing artists, intersectionality

\section{Introduction}

In March 2020, social distancing was introduced in Austria as well as in many parts of the world as a preventative response to the threat of the COVID-19 pandemic. As a result, as of this writing the live music scene has been shut down for weeks, in some parts of the world even for months. The music industries had to deal with these consequences, with many musicians losing their income and source of livelihood. Musicians and performers had to explore alternative modes of income from their art during times of social distancing. Free access to the internet, and the introduction of social networking services such as Myspace and online video 
platforms such as YouTube or Vimeo, allowed musicians from around the world to upload their music and develop virtual audiences (Roy et al. 2019). Online domains became the main platform for freely available music and performances, with artists globally broadcasting themselves through live social media streams during the pandemic. This practice is not new in the music industry, but the cancellations of on-site live performances have led to a shift from offline live shows to online live streams. Streamed concerts were celebrated as an antidote to crisis that highlighted the benefits of performing art in times of isolation, but consequently this risked normalizing the idea that musicians are performing for no compensation even though the online music community base Bandcamp renounced their own revenue share for twenty-four hours on Friday, 20 March, to support musicians and to raise awareness of the live music sector's plight during the shutdown (Diamond 2020).

Viennese musicians and concert venues such as Ernst Molden, Mira Lu Kovacs, Der Nino aus Wien ("Nino from Vienna"), or the jazz club Porgy \& Bess, started to broadcast live-streamed concerts in March 2020. The well-established blues musician Ernst Molden began his weekly balcony concerts with the song "O du lieber Augustin". The ballad singer and bagpiper Marx Augustin presumably composed the popular tune when the Great Plague struck Vienna in 1679. Augustin became a national symbol for charming humour in bitter times. By using the wellknown melody, Molden turned into the artistic savior for the Viennese crowd. The crossover musician Mira Lu Kovacs recorded Enya's "Only Time" and released it on Spotify to promote her appearance at the Home Stage Festival. The virtual festival was linked to a crowd funding campaign, and its proceeds shared equally among all artists and organizers. Indie rock musicians such as Der Nino aus Wien or Voodoo Jürgens celebrated their album releases with living room concerts, while jazz fans were invited to attend performances virtually via live streams from the jazz club Porgy \& Bess. Besides popular music, other genres also went online; Vienna's State Opera offered live-streamed concerts in spring and autumn 2020 (sofe 2020).

The COVID-19 pandemic acted as a cultural catalyst that spread art and other cultural outputs around the globe. This may exert a long-term influence on cultural and aesthetic expressions. It has the potential to expose musical micro-cultures to a larger and especially geographically dispersed audience by expanding the expression of cultural diversity. Live music as an integral part of Vienna's culture allows individuals to be part of a certain collective. A classical symphony concert, as the epitome of the "correct" perception of music with a hundred highly specialized musicians on stage and around 2,000 listeners, is closely connected with the actors' self-image of making a contribution to national identity and thus consolidating and deepening the political status quo. When neoliberalism took hold in Austrian cultural policy in the 1990s, the traditional music business saw the opportunity to claim greater independence. With lockdown measures in midMarch 2020, season plans became obsolete and the audience was forced to stay at home. The question of the value of live music arose when the lockdown revealed that Austrian society functioned without any live events, with the outcry from the population (but above all from politics) being limited. A seemingly indestructible business model came to an abrupt end. The collapse of the market led to the question of how a new beginning could be instituted. If the cultural policy of the past few years has achieved anything, it was the implementation of the system "divide and conquer" with the basic idea to decompose a given problem into various similar, but simpler, subproblems, solve them in turn, and consequently compose their solutions to solve the given problem. This idea dates back at least as far as Babylonia in 200 BC. The result was an isolation of the actors within the 
music business, who perceived each other in mutual competition. What had been lost was the ability to communicate with one another on key issues, despite all the competitiveness, and to practice cooperation, but the COVID situation has caused it to return. Such a new cooperative attitude necessarily led to the expansion of artistic professions, which includes organizational and regional development as well as educational and social work.

This article discusses the intersection of live music with social and cultural issues, focusing on Vienna's popular music scene during the COVID-19 pandemic. I begin my inquiry with a brief survey of the expanding area of live music research, primarily based on the works of Philip Auslander and Simon Frith. Throughout the text, I turn a critical eye to the broad impacts of the pandemic on music-making, based on the experience of the aforementioned musicians, and the ways in which the potentials of emerging digital communities are leading to changed forms of appreciation. Along the way, I will address strategies in which musicians have harnessed digital technologies to connect with fans and to network with peers and industry. This argument will be based on systematic reviews of performances, interviews, and posts in social media. Beyond the need to focus on gender when questioning socially produced differences and resulting social inequalities, I will also reflect on other categories such as class, body, and generation.

\section{Strategies of Live Music Research}

The term performance has been studied for decades, but the category of live performance started to gain scholarly attention in the early 2000s. The economic growth in the live music industry can be regarded as catalyst for this research interest, including talent shows on TV, music videos, and the streaming of concerts on YouTube, Facebook, or Instagram. In 2007, Simon Frith contributed with his article "Live Music Matters" to the rethinking of live music in popular culture by providing an insight into the UK's situation and criticizing sociology for not interrogating the difference between live music markets and the markets of media music, as well as the differences between live and media experience. Fabian Holt's article "The economy of live music in the digital age" (2010) develops the concept of live music as an experience. The author's approach includes considering the rise of secondary performances, as exemplified by cover bands and tribute bands, as well as talent shows and karaoke. In 2015, Simon Frith discussed "the value of live music" in an article with the same title. He defines this value in an economic and in a cultural way. Live music can be regarded as a source of income, as well as being experienced as something that is valuable and cannot be monetised. With most analyses of the live music sector being focused on its economic value, I am more interested in the aesthetic value.

At the height of music television, Philip Auslander's thesis is that experiences of authentic liveness are strongly connected to our "mediatized culture" (1999: 32$35,50,85-94)$. The perception of liveness is inevitably contaminated by our experience with technical media. Auslander's book can be regarded as a major contribution to the field of live music research, but his categories of media and performance are rather general, conveying a postmodern narrative of mediatization. Twenty years after the publication of Auslander's book, we are used to watching recordings of live performances on YouTube and other social media channels and reacting to these performances via comments, likes, or shares. Live performances can be regarded as influenced by mediatization, with the development of recording technologies as a starting point. Without the 
establishment of something recorded, we would not be able to distinguish between a recorded and a live performance. Even though Auslander's study brought new attention to live performance, questions such as how the identification of a concert or a DJ set as live music informs cultural practice remained unanswered.

With popular music concert production becoming professionalized and internationalized, concerts can be regarded as one of the main sources of income for many musicians. Even before the age of COVID-19, live music had found a new cultural location in networked digital media. During the last fifteen years, live music and its experience gained some specific sorts of cultural value such as musical creativity, cultural identity, heritage, cultural vibrancy, or talent development (van der Hoeven and Hitters 2019) in popular culture. In terms of the temporal and spatial dimensions, digital communication has become more flexible. Media representations of performance shape the culture of performance. By offering bodily co-presence in a social and material space, the live performance involves an active and social form of consumption. Fans are able to share their experience with friends and strangers in the audience. Philip Auslander (1999: 64) suggests that "it is surely the case that a sense of community may emanate from being part of an audience that clearly values something you value, though the reality of our cultural economy is that the communal bond unifying such an audience is most likely to be little more than the common consumption of a particular performance commodity". As Fabian Holt (2010: 255) states, "the desired experience of communitas is replaced by solitude when audiences have little experience, and mainly experience mediated and presentational rather than participatory performances". By regarding a concert as a media experience, we notice that the audience expects artists to satisfy individual expectations. This on-site musical performance is defined by spontaneous interaction with the audience.

Since the 1990s, the live sector has gained more economic success, while the record industry has been undermined by digital technology. In his 2015 article "The Value of Live Music", Simon Frith (2015: 20-21) proclaims:

By 2025 there will be no stadium gigs. (...) By 2025, though, there will be no record shops, but then there will be no record companies either. (...) In the 2025 economy of commercial musical services the model for what, in the era of the musical product, were called distribution and promotion will be radio and, more specifically, BBC Radio. (...) By 2025 there will be three distinctive musical worlds, which, in business terms, will be organised by different kinds of company and entrepreneur: the dance music world, organised around the provision of sounds and spaces for dancers; the talent music world, organised around the provision of performers for visual media entertainment shows and songs for adverts, soundtracks, private pay systems and shopping malls; and the art music world, organised around the ideology of music as art, something up-lifting and transcendent, a source of national pride and an activity requiring state educational and financial investment.

By connecting Frith's thoughts with the current developments, we could expect that the live music sector with its recurring lockdown measures will continue to move into the digital area. How this area can compensate for the loss of concert income will be examined in the following section. 


\section{Performing Artists and the COVID-19 Pandemic in Vienna}

With the beginning of the Corona crisis, so-called balcony concerts became part of the cultural landscape in Vienna. On the first weekend of the shutdown at 6 p.m., people gathered on their balconies, musicking together or turning up Rainhard Fendrich's "I am from Austria" (1989). The song is considered one of the most popular songs in Austrian language (APA 2017) even though its title is in English. It was used by the Austrian police to thank the citizens for their behaviour in accordance with measures against the pandemic. Every day at 6 p.m., the song was played by police patrols and on the regional broadcast "Radio Wien" (Red 2020a).

The well-established blues musician Ernst Molden started his weekly balcony concerts with the song "O du lieber Augustin". The ballad singer and bagpiper Marx Augustin presumably composed the popular tune when the Great Plague struck Vienna in 1679. Augustin toured the city's inns to entertain people. The musician was well-known and appreciated for his charming humour in bitter times, so the Viennese audience started to call him Lieber Augustin ("Dear Augustin"). According to legend, he fell in the gutter when he was drunk and was mistaken for a dead man by the gravediggers who patrolled the city for dead bodies. As a consequence, he was thrown with his bagpipes into a pit filled with dead plague victims outside the city walls. When Augustin woke up, he was unable to get out of the deep mass grave, and therefore started to play his bagpipes. He was rescued and remained healthy even though he spent hours next to infected dead bodies (Schmidt 1947: 73).

The tune was first recorded in Vienna around 1800 . The very common melody is older, as it is documented in a music manuscript in 1720. Augustin himself is sometimes named as the author, though the tune's origin is unclear. The mocking text reflects the gallows humour that the Viennese remember:

O, you dear Augustin, Augustin, Augustin,

O, you dear Augustin, all is lost!

Money's gone, girlfriend's gone,

All is lost, Augustin!

O, you dear Augustin,

All is lost!

Coat is gone, staff is gone,

Augustin lies in the dirt.

$\mathrm{O}$, you dear Augustin,

All is lost!

Even that rich town Vienna,

Is broke like Augustin,

Shed tears with thoughts akin,

All is lost!

Every day was a feast,

And now?

The plague!

Just a great corpse's feast,

That is the rest.

Augustin, Augustin,

Lie down in your grave!

$\mathrm{O}$, you dear Augustin,

All is lost! (1)

Augustin became a national symbol for charming humour in bitter times. The song was a popular theme for variations during the classical era, used by composers such 
as Paul Wranitzky, Johann Nepomuk Hummel, or Anton Stadler. The melody also appears at the end of the song "Spinning Wheel" by Blood, Sweat \& Tears, written by David Clayton-Thomas.

From 15 March to 21 May, at exactly 6 p.m., Molden performed every Wednesday and Sunday, for a total of twenty gigs from the balcony of his apartment in Vienna-Erdberg. Molden's gigs lasted around a quarter of an hour and were performed as solo acts or duo acts with his son Karl on bass or his brother Berthold on harmonica. The musician announced one of his first gigs on Facebook: "Dear folks, I would have announced a handful of shows these days, over a dozen concerts up into May. Unsurprisingly: I don't have to anymore, because everything has been cancelled anyway. What I'm doing instead: cleaning windows, cooking, writing, and translating. Two times a week, I enter my balcony in Erdberg and sing a few songs for the neighbourhood" (2). Up to a hundred fans listened to these gigs from their balconies or on the streets. As cited in the newspaper Der Standard, Molden calls it "a nice exercise", although he had to remind the large crowd of social distancing; "The whole thing has become a little touristy" (Wurmitzer 2020). In order to let all fans participate in his balcony concerts, Molden put his appearances on YouTube. Announcing one of his last gigs on Facebook, Molden highlighted the positive effect of the crisis:

\begin{abstract}
Dear folks, The BALCONY CONCERTS on Wednesdays and Sundays of the last few weeks have grown dear to my heart: I have had the feeling that my profession is not quite as forbidden as it has been suggested recently. I got to know the world's best neighbourhood, namely mine, from its most beautiful side. (...) And during that process I founded a duo with my son KARL MOLDEN! (...) I would like to announce the following: this was the third last balcony concert. At the end of May, I'm starting to record an album with the FRAUENORCHESTER, and the developments give us hope for the first cautious shows in the summer. (3)
\end{abstract}

Molden recurrently referred to the "Zeiten der Fledermauspest" ("times of the bat plague") on his Facebook artist page. Consequently, the public persona Ernst Molden became an artistic saviour in "times of the bat plague". The repertoire of his balcony concerts consisted mostly of his own songs. He, therefore, used this special stage as a promotion tool. Molden's balcony performances cannot be regarded as compensation for the loss of concert income but as a stage to promote his available and future recordings. During his last gig, records and books were sold by his manager (Molden 2020). Molden also appeared at the Donauinselfest ("Danube Island Festival") tour bus that toured through Vienna from July to September (Fig. 1). The Donauinselfest is a free open-air music festival hosted by the Sozialdemokratische Partei Österreichs (Social Democratic Party of Austria), and occurs annually in Vienna. The festival is the world's largest open-air music festival, with around three million visitors over three days (Reality Check Team 2018). In 2020, the festival was extended for 80 days, with gigs in public spaces all over Vienna. Over 100 local artists and bands performed on the stage of a doubledecker bus. 240 pop-up events have been announced, including readings and cabaret performances (Donauinselfest 2020). The exact timetable and locations were revealed only a few hours before each gig in order to avoid large crowds. Ernst Molden performed three solo shows on 10 September 2020. His repertoire consisted of his own compositions and a cover version of the Austropop song "Der Tschik" ("The Cigarette") by Georg Danzer. Additionally, Molden's recordings were sold by his manager. 


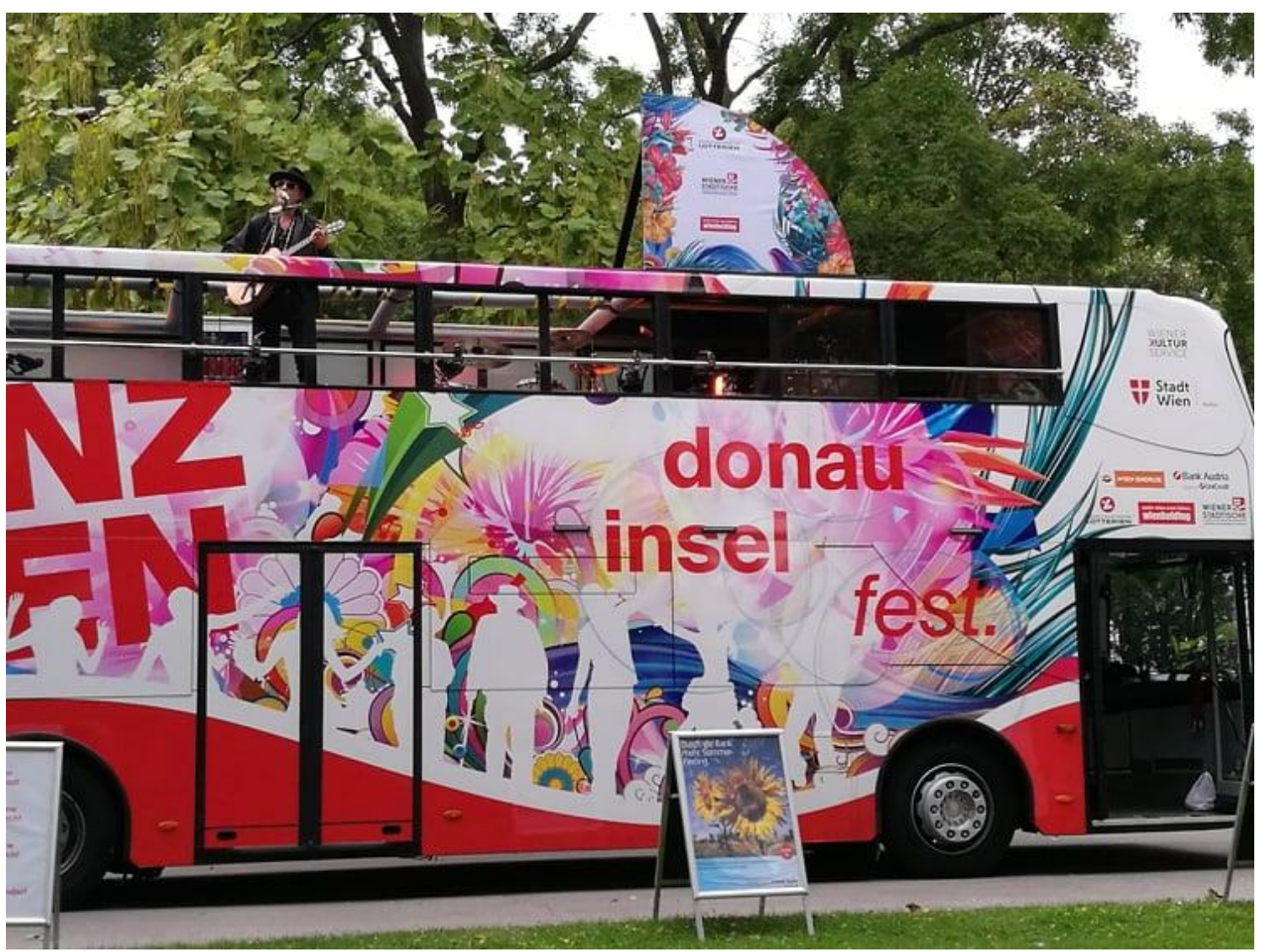

FIGURE 1: Ernst Molden performing a bus gig, @ Magdalena Fuernkranz

Molden also advised his audience to attend concerts after the lockdown. Musicians have helped audiences through the crisis while encouraging audiences to help musicians out of the crisis. With the recordings of his live events, Molden gained a bigger audience that was able to be part of his performances without being bodily co-present. The active and social form of consumption happened one-site, and was simultaneously transferred online. In terms of Auslander (1999: 64) these free concerts created a "sense of community" that was celebrated on- and offline.

The crossover musician Mira Lu Kovacs recorded Enya's "Only Time" and released it on Spotify to promote her appearance at the Home Stage Festival. As she wrote on Instagram, Kovacs never thought about the lyrics of "Only Time", with lines such as "Who can say where the road goes / Where the day flows / Only time", she described the song as "full of magic" (Dulle 2020). The Home Stage Festival was a virtual festival linked to a crowdfunding campaign, its proceeds shared equally among all artists and organizers. The first Homestage Festival took place from 27 March to 29 March from 5 p.m. to 9 p.m.; the second edition was streamed from 24 April to 26 April. In keeping with the slogan "Stay home. Stay safe. And support your local artists" (Red 2020b), various Viennese artists streamed their performances live from their living rooms to the audience's homes. The events offered a wide mix of different genres. Based on the idea of bringing together wellknown and lesser-known artists from different genres, showing solidarity, enabling artists to perform in times of crisis and to reach new audiences, the festival was initiated and curated by Raumpioniere Agentur für Stadtmacher ("Spatial Pioneers Agency for City Creators") and the concept agency Visionistas from Vienna. With artists facing massive challenges, fans supported them by donation-based crowdfunding, wherein not only tickets but announcements via live-stream could 
be purchased, even though the curators provided the opportunity to attend free of charge (Sahlender 2020). The ticket proceeds were paid out equally among the participating acts. The members of the festival team counted as "artists" and also participated, receiving the same amount as each artist. From the total amount reached, a one-off $2 \%$ was deducted in order to pay the online trustee who managed the financial support. The first funding goal for the first edition was $7,000 €$, the second goal was 15,000€; the initiative backed $15,748 €$. The first funding goal for the second edition was 5,000€, the second goal was 15,000€; the initiative only backed 5,540€ (Raumpioniere 2020). The crowdfunding campaign was promoted via Facebook with a video of the performing artists giving reason to purchase festival tickets. The video received 96 likes and two comments total, both referring to the paywall system (Homestage Festivals Facebook 2020). Artists, such as Violetta Parisini, promoted the crowdfunding campaign during their performances or referred to the baby elephant as an Austrian social-distancing symbol (Homestage Festivals 2020). Regarding their repertoire, musicians usually promoted their own songs; performers, such as Ines Kollaritsch or Mira Lu Kovacs (Homestage Festivals 2020), played cover versions of songs that influenced their careers. Some artists performed in their living rooms with guitars or other acoustic instruments, such as Ernst Molden; other musicians, such as Pippa, performed in studio-like settings (Homestage Festivals 2020). It is significant that topics such as class or race were hardly discussed in the different performances.

Forty-two acts appeared at the Home Stage Festivals; the majority performed as solo acts even though most of the musicians were part of band collectives. Musicians who played together were located in the same room except the Wiener Beschwerdechor ("Viennese Complaint Choir"), whose forty-three singers performed with the support of the video conferencing tool Zoom. The choir's website reveals that the choir started virtual rehearsals in April 2020 (Wiener Beschwerdechor website 2020). According to the Ö1 Morgenjournal, each artist involved, the two sound engineers, and the festival team's four employees earned $600 €$ each (Elstner 2020). The organizer Lisa Wachitz stated that some artists renounced their fees in favour of less well-known colleagues, who were hit harder by the current situation (Feichter 2020). A large number of the musicians who participated in the Homestage Festival were so-called digital natives. Concerning the comments that referred to the linked performances on the festival's Facebook page, the digital natives are the target group that interacts the most. Holt (2010: 255) mentions the solitude that arises when a group "mainly experience mediated and presentational rather than participatory performances". Consequently, I assume that watching concerts for free online is already part of the digital native's consumer behavior. It seems that a "sense of community" (Auslander 1999: 64) could not be developed, as the second part of the festival failed to achieve its financial goals.

Indie rock musicians, such as Der Nino aus Wien or Voodoo Jürgens, celebrated their album releases with living room concerts. In March 2020, Der Nino aus Wien called his one-hour long concert, which was streamed via YouTube, "live in isolation" (Fig. 2). "Nino, the corona blues killer", as one of his fans named him, performed in front of a monstrous microphone, which was only a prop, and recorded on his iPad. By wearing his Ray-Ban shades, he resembled the young Bob Dylan. He remarked that he missed the applause. The lack of cheers could only be compensated for by the viewers' comments. As a small gesture of gratitude, Der Nino aus Wien responded to the wishes of his enthusiastic audience as he played requests. From time to time, he placed filters over the video image, creating a psychedelic atmosphere, or deconstructed the serious performance with effects 
such as soap bubbles. This was meant to be the "sensational light show" the singer had promised on his earlier post on Facebook. More than 3,532 people watched the performance via YouTube (Trenkler 2020). The gig started with "Plurabelle", which was followed by several hits such as "Winter im April" ("Winter in April"), "Der Mai ist vorbei" ("May is over"), "Praterlied" ("Prater Song"), and "Du Oasch" ("You, asshole"), wherein he had to sing the duo-parts himself. Additionally, Der Nino aus Wien introduced a new song called "Taxi Driver".

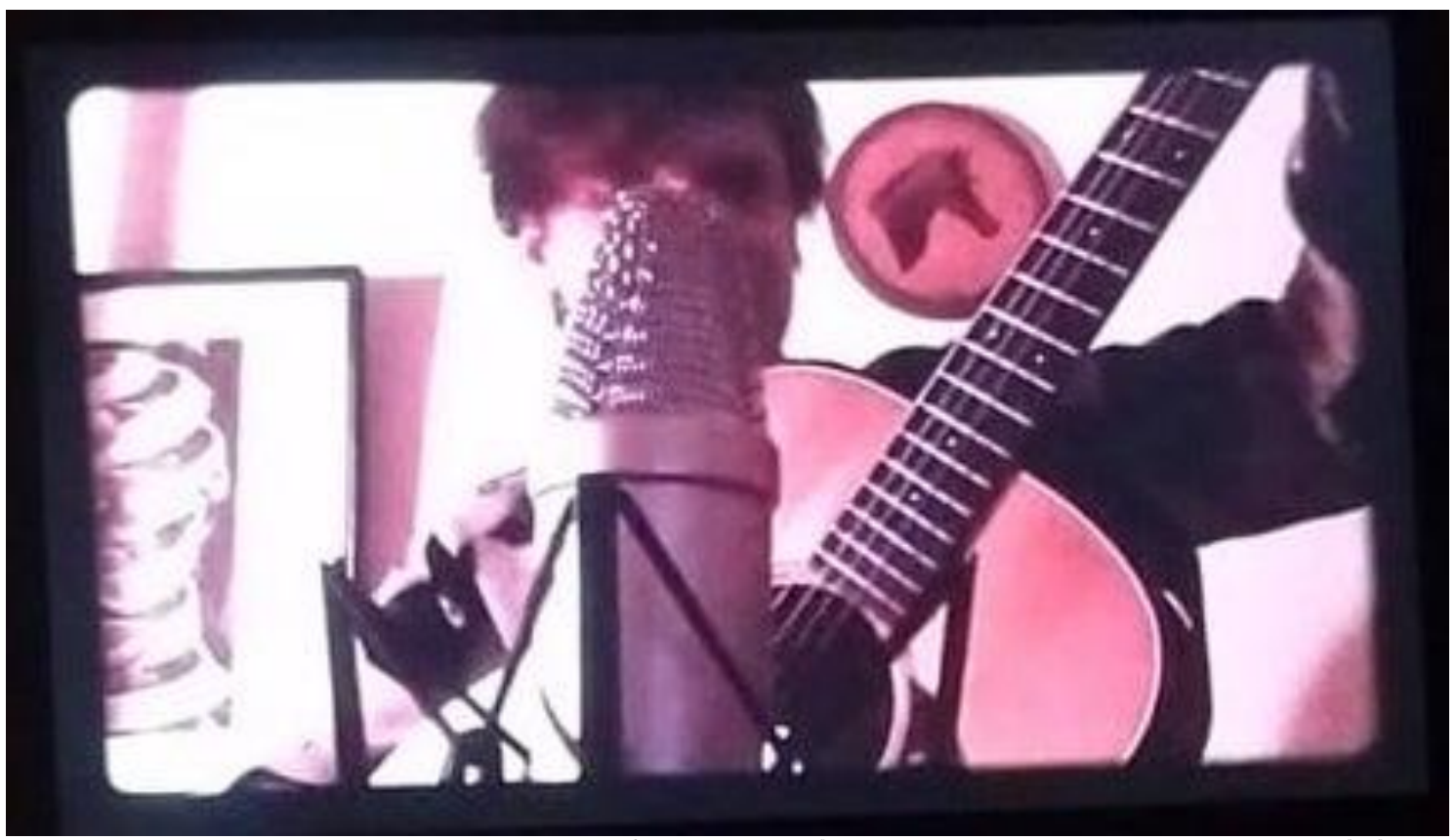

Figure 2: Der Nino aus Wien performing a living room concert, (c) Magdalena Fuernkranz

The audience discussed the painting of a horse that could be seen in the background and wondered what the singer was drinking from his mug. It was red wine, as the artist, holding the bottle in the camera, admitted. As an encore, he sang "Schlagoberskoch" ("Whipped Cream Cook") due to popular demand. Der Nino aus Wien plays around 100 gigs a year (Fluch 2020), and most of these planned concerts had to be cancelled including one gig at Austria's largest indoor arena, the Wiener Stadthalle.

Voodoo Jürgens is another indie rock artist who is famous for his live performances. On 1 May 2020, he posted via his Facebook page "Today at 9:30 p.m. we will gather at Problembär's Youtube channel and have a concert. To be honest, I'm a little nervous, but I'Il work it out" (4) (Voodoo Jürgens Facebook Page 2020). On 5 June, the artist released an updated version of his album 'S klane Glücksspiel ("The little gambling"), which included an exclusive bonus track, new artwork painted by the musician, and a special vinyl edition. The gig was professionally recorded by the label Problembär Records in the artist's flat and was promoted as "At Home Session" on the Problembär YouTube channel with over 1,000 people virtually attending. Voodoo Jürgens also played a series of gigs in a former peepshow that offered acts from Vienna's cultural landscape for two weeks. The audience observed the intimate shows in cabins (Kobler 2020).

The four-day festival Wiener Popfest (Viennese Popfest), which regularly takes place on Karlsplatz, a public space in Vienna, was reduced to just four acts due to 
the COVID-19 pandemic. The curators Esra Özmen (Esrap) and Herwig Zamernik (Fuzzman) changed the venue from open air to the Karlskirche (St. Charles' Church). The pastor, Peter Fiala, pointed out that the church was erected during the great plague in Vienna in 1713 and the sacred building was dedicated to the plague saint Karl Borromeo (Köck 2020). Voodoo Jürgens was one of the four acts who performed at the festival. He played guitar and melodica and was accompanied by a bottle of wine. As the journalist Samir Köck remarked, Pastor Fiala was not bothered by the fact that the musician disregarded the wine monopoly of the church (Ibid.). Voodoo Jürgens ignored the church etiquette and sang openly about gambling, alcohol, and sexuality. The musician performed the duet "Gitti" solo, and also changed voices for the song "Drei G'schichten aus dem Café Fesch" ("Three stories from Cafe Doggy"). Der Nino aus Wien and Voodoo Jürgens could not generate an adequate replacement for the loss of income during lockdown. Additionally, Der Nino aus Wien's live-streamed concert proceeds were donated to charity. Nevertheless, the two artists showed creativity in dealing with the crisis. Nino's bandmate, bassist PauT, accompanied the living room concert via his Instagram live-feed. The promoted light show turned out to be an iPad photo filter. The singer Voodoo Jürgens performed in unusual locations, such as a church or a peep show. The choice of locations and the cooperation with various organizers demonstrate the creative potential of the Viennese cultural scene. Additionally, it underlines Voodoo Jürgens's controversial public persona. Der Nino aus Wien and Voodoo Jürgens used their popularity and their images as indie rock stars to promote their album releases with living room concerts. These concerts can be read as a promotion tool in order to maintain a certain live community. The musicians gave an insight into their supposedly private space, but the focus was still on the promotion of their new releases. The audience was allowed to interact with each other and with the artists via comments. This interaction created "a communal bond unifying such an audience" that can be regarded as being "little more than the common consumption of a particular performance commodity" (Auslander 1999: 64).

Jazz fans were invited to virtually attend performances via live stream from the jazz club Porgy \& Bess, a "jazz \& music club with a pluralistic and multifaceted programme" (Porgy \& Bess website) that was founded in 1993. The first gig was performed by the duo 4675 (Astrid Wiesinger and Beate Wiesinger), and was viewed over 250 times, with around two-thirds accepting the invitation to pay a freely selectable ticket price. A total of about 1,000€ was raised, which covered the concert costs, musicians' fees, and technicians' fees. The club owner Christoph Huber presented the online concert series as a "jazz delivery service" (Feichter 2020). Between April and June, twenty-nine gigs took place at Porgy \& Bess that were attended virtually by the audience.

It seems that especially the jazz scene struggled with live-streaming concerts performed in the artists' living rooms. In an interview with mica - music Austria, the musician Judith Ferstl remarked that she did not feel the need to stream from her living room, but she did enjoy playing once from her balcony (mica - music Austria 2020b). Jazz musician David Helbock also criticized the tendency to stream music online for free: "(...) there are many live-streams and most of them are free. Earning money is not happening now anyway. But I'm afraid that this is not useful to anyone, because the idea of 'music/art is not worth anything, doesn't cost anything' is even more reinforced" (mica - music Austria 2020a). Viola player and singer Jelena Popržan stated that the music scene should invest in a solidarity struggle against inequality and discrimination. She mentioned that she missed the 
direct human contact: "Streaming is certainly satisfying for a short time, but of course not an alternative. It's just an attempt to stay on the ball and keep us happy" (mica - music Austria 2020a). The singer Golnar Shahyar takes a different approach. She conveyed some of her activities online and described streamed live events as an alternative option to stay active and generate an income. Her future plans include the expansion and strengthening of her network online (mica - music Austria 2020c). Percussionist Manu Delago also live-streamed from his home while using the breaks in between for composing (mica - music Austria 2020c). The interviews conducted by mica - music Austria reveal a critique of live-stream concerts, but also the use of live-stream concerts to secure a living and to draw creative potential from these shows. Regarding the genre jazz and the refusal of several jazz musicians to stream their music for free, I refer to Simon Frith's proclamation. Jazz is often regarded as "art music" with most of its performers being highly educated and well-respected as "serious musicians." Frith states that in 2025 the art music world will be one of "three distinctive musical worlds," it will be "organised around the ideology of music as art, something up-lifting and transcendent, a source of national pride and an activity requiring state educational and financial investment" (2015: 20-21). If Frith's proclamation becomes reality, streaming events as promotion tool will become obsolete for this musical world.

\section{Conclusions}

During the COVID-19 pandemic hardly any other area has been hit as existentially as the cultural industries. Particularly, the lockdowns and their medically required restrictions on social life had a drastic effect on all areas that apply to concrete experience of art and culture in people's everyday lives. Large parts of the creative industries are threatened in their existence; regarding the area of popular culture, cultural work is often carried out by independent personnel without fixed institutional ties. With the COVID crisis, various discussions about the value of streaming concerts came about. Some missed the aura of the live experience; others called on peers not to perform for free. Media theorist Peter Weibel announced the end of the age of proximity. Weibel proclaims a turning point through the end of mass mobility and its environmentally harmful side effects. He asserts that "(...) the games and concerts are not serving the local mass audience, but the non-local masses, the virtual worldwide audience, sitting in a decentralized way in front of TV sets and tablets" (Weibel 2020). It seems that the mentioned audiences wanted to support streaming artists, as a study by Bandsintown revealed "more than $70 \%$ of fans are willing to pay to provide financial support for streaming artists" (Courtney 2020). With the popularity of online shows, questions of authorship, recording and reproduction rights concerning different platforms and national legal systems have been raised.

The outbreak of COVID-19 reinforced the digitization of culture, pointed out the need for change, and affected the reconsideration of the value of live performances. With the lack of practice spaces and recording opportunities, the development of new recordings was made more difficult. Artists such as Mira Lu Kovac recorded cover versions of songs to promote their appearances at online festivals or living room concerts. These virtual festivals illustrate that the economic disruption impacts beyond the artists themselves. With the cancellations of music festivals, local economic actors such as crew members, roadies, security agents, and merchandise sellers, were facing unemployment. The public debates and lockdown measures caused an interruption of cultural and creative industries, wherein processes of 
cultural policy and the promotion of popular culture are being disrupted. It seems that popular culture tends to be forgotten as a catalyst to an open and participatory society. Consequently, damages to the cultural landscape as a whole and other economic sectors, such as tourism or gastronomy, can be expected.

In this article, strategies through which musicians have harnessed digital technologies to connect and network with fans, other artists, and industry were examined based on systematic reviews of interviews, performances, and posts in social media. This mixed methodological approach allows the musicians portrayed here to share their ideas and experiences; additionally it gives an insight into the on- and offline reception of their musicianship, into new possibilities of examining social media platforms in times of crisis, and into using social media for social research. The ways of dealing with the crisis have varied between genres. It seems that age or professional experience did not impact the creative potential: Male indie musicians used free concerts as a promotional tool, while female musicians compensated their loss of income with donation-based gigs. By regarding female musicianship, the creative potential in dealing with the crisis became more evident. Concerning the genre jazz, we find musicians refusing to give free online concerts, but attending donation based streaming concerts in jazz clubs. Musicians, who were active in this genre were in need of institutional support and preferred the atmosphere of a stage. Streaming from the living room provides an insight into the artists' own spaces, consequently it is a question of class and accessibility, a privilege to give this intimate insight. Different genres deal with different approaches and staging concepts. Regarding the body as an historical idea or situation, it is the centre of the stage performance. With no stage available, musicians are prevented from engaging the audience at a concert, encouraging participation or changing up the audience's mood. Regarding the aspect of race, the Viennese music scene seems predominantly white. Black, indigenous, and people of colour became even less visible during the crisis.

Digital communication has become more flexible in terms of the temporal and spatial dimensions. While live performances involve an active and social form of consumption, with fans being able to share their experience, artists had to find a way to transfer this form of interaction online. Regarding this transfer process, I connected the theoretical considerations of Auslander and Frith with the current developments. Free streaming concerts with on-site bodily co-presence created a certain "sense of community" (Auslander 1999: 64) that was celebrated on- and offline and allowed the audience to interact. Watching those concerts online can be regarded as a part of the digital natives' consumer behaviour; it seems that this group refuses to pay or donate for streaming concerts. The management of popular indie rock musicians, such as Der Nino aus Wien or Voodoo Jürgens, accepted this fact and used the streaming concerts of the aforementioned artists as promotion tools for album releases. Concerning the jazz genre, its musicians identify predominantly as "art musicians"; regarding Simon Frith's proclamation I assume that this genre will become "a source of national pride" (2015: 20-21).

As David Hesmondhalgh reminds us, listening to music plays a significant role in our lives; it symbolizes an intense and emotional personal experience (Hesmondhalgh 2013: 2). With the shutdown of live venues, expressions of emotion were transferred to online platforms as an open space where artists and fans could not only meet but also support each other. The bands and musicians portrayed here as examples demonstrate that the crisis does not affect artistic practices in an entirely negative way. "Free concerts" can be regarded as the search of new audiences, new forms and formats of interaction, and as a way out of the crisis. 
Even though we cannot predict how the COVID-19 pandemic will influence musical expression, it will undoubtedly work as a catalyst for change.

\section{Endnotes}

(1) O du lieber Augustin, Augustin, Augustin, O du lieber Augustin, alles ist hin. Geld ist weg, Mädl ist weg, Alles hin, Augustin. O du lieber Augustin, Alles ist hin. Rock ist weg, Stock ist weg, Augustin liegt im Dreck, O du lieber Augustin, Alles ist hin. Und selbst das reiche Wien, Hin ist's wie Augustin; Weint mit mir im gleichen Sinn, Alles ist hin! Jeder Tag war ein Fest, Und was jetzt? Pest, die Pest! Nur ein groß'Leichenfest, Das ist der Rest. Augustin, Augustin, Leg' nur ins Grab dich hin! O du lieber Augustin, Alles ist hin! (Transcription and translation by the author)

(2) "Liebe Menschen, an dieser Stelle hätte ich dieser Tage eine feiste Handvoll Shows angekündigt, ein gutes Dutzend Konzerte bis in den Mai hinein. Wenig überraschend: ich muss es nicht mehr, denn das ist eh alles abgesagt. Was tue ich stattdessen: Fensterputzen, Kochen, Schreiben und Übersetzen. Zweimal die Woche trete ich auf meinen Erdberger Balkon und singe ein paar Lieder für die Nachbarschaft." (Ernst Molden Facebook Artist Page, 24 March 2020; translation by the author).

(3) "Liebe Menschen die BALKONKONZERTE an den Mittwochen und Sonntagen der letzten Wochen sind mir ungeheuer ans Herz gewachsen: ich habe das Gefühl gehabt, dass mein Beruf doch nicht ganz so verboten ist, wie es mir in letzter Zeit manchmal suggeriert wird. Ich habe die beste Nachbarschaft der Welt, nämlich meine, von ihrer schönsten Seite kennengelernt. (...) und ich habe, in the process, mit meinem Sohn KARL MOLDEN ein Duo gegründet! (...) Ich möchte Folgendes verlautbaren: dies war das vorerst drittletzte Balkonkonzert. Ende Mai beginne ich mit dem FRAUENORCHESTER eine Platte aufzunehmen und die Entwicklungen machen Hoffnung auf ersten vorsichtigen Shows im Sommer." (Ernst Molden Facebook Artist Page, 13 May 2020, translation by the author).

(4) "heit um 21:30 treff ma sie olle beim probembär youtube auf a konzertal. ehrlich gsogt geht ma bissl da reis owa wird scho hinhaun. bis späda." Translation (German): "Heute um 21:30 treffen wir uns alle zu einem Konzert auf dem YouTube-Kanal von Problembär Records. Ehrlich gesagt, bin ich etwas nervös, aber es wird schon klappen. Bis später." (Translation by the author).

\section{References}

\section{Bibliography}

Auslander, P. 1999. Liveness: Performance in a Mediatized Culture. New York: Routledge.

Carson, C., \& Westvall, M. 2016. Intercultural Approaches and "Diversified Normality" in Music Teacher Education: Reflections from Two Angles. Action, Criticism \& Theory for Music Education 15 (3): 37-52.

Courtney, I. 2020. Bandsintown Becomes A Hub For Music Live-Streaming. Celebrity Access, 21 April. https://celebrityaccess.com/2020/04/21/ bandsintown-becomes-a-hub-for-music-live-streaming/. Accessed: 14 December 2020.

Diamond, E. 2020. Today, Support Artists Impacted by the Covid-19 Pandemic. Bandcamp Daily, 17 March. https://daily.bandcamp.com/features/bandcampcovid-19-fundraiser. Accessed: 15 December 2020. 
Dulle, P. 2020. Mira Lu Kovacs covert "Only Time" von Enya. Profil, 25 March. https://www.profil.at/kultur/songs-gegen-corona-mira-lu-kovacs-covert-onlytime-von-enya/400890107. Accessed: 14 December 2020.

Elstner, R. 2002. Retten Streamingprojekte die Musikbranche? Ö1, 16 May. https://oe1.orf.at/artikel/670612/Retten-Streamingprojekte-die-Musikbranche. Accessed: 14 December 2020.

Feichter, B. 2020. Kultur online: Pay as you wish. Ö1, 10 May. https://oe1.orf.at/artikel/670307/Kultur-online-Pay-as-you-wish? fbclid= IwAR0_y-ZDHeVzUjXSn3rEIImpc4rwkt5TLVDgwA2oqOuomYZvplqLMnHI8k. Accessed: 14 December 2020.

Fluch, K. 2020. Momentaufnahmen von Nino aus Wien: "Ocker Mond". Der Standard, 6 May. https://www.derstandard.at/story/2000117319555/momentaufnahmen-vonnino-aus-wien-ocker-mond. Accessed: 14 December 2020.

Frith, S. 2013. The Value of Live Music. In D. Helms and T. Phleps Eds. Ware Inszenierungen. Performance, Vermarktung und Authentizität in der populären Musik. Bielefeld: Transcript: 9-22.

Hesmondhalgh, D. 2013. Why Music Matters? Malden, MA: Wiley-Blackwell.

Holt, F. 2010. The Economy of Live Music in the Digital Age. European Journal of Cultural Studies 13 (2): 243-261.

Kobler, F. 2020. Corona-Konzerte in der Peepshow. ORF, 31 May. https://wien.orf.at/stories/3051201/. Accessed: 14 December 2020.

Köck, S. 2020. Grandiose Corona-Edition des Popfests mit Vodoo Jürgens. Die Presse, 26 July. https://www.diepresse.com/5844737/grandiose-corona-editiondes-popfests-mit-vodoo-jurgens. Accessed: 14 December 2020.

Kornhaber, S. 2020. Pop Music's Version of Life Doesn't Exist Anymore. The Atlantic, 19 March. https://www.theatlantic.com/culture/archive/2020/03/whatgood-is-pop-music-during-the-coronavirus-pandemic/607894/. Accessed: 15 December 2020.

Red 2020a. Fendrich zu Polizei-Aktion: "Bin sprachlos". ORF, 21 March. https://wien.orf.at/stories/3040243. Accessed: 14 December 2020.

Red 2020b. Online-Festival für heimische Künstler. $O R F, 21$ March. https://wien.orf.at/stories/3040162/

Redaktion 2006. Als einen Sommer lang Freiheit war. Der Standard, 22 August. https://www.derstandard.at/story/2492068/als-einen-sommer-lang-freiheit-war.

Accessed: 09 December 2020.

Reality Check Team 2018. Music Festivals: What's the World's Biggest? BBC News, 4 July. https://www.bbc.com/news/world-44697302. Accessed: 14 December 2020.

Roy, D. et al. 2019. Teaching the Arts: Early childhood and primary education. (3rd Ed.). Cambridge: Cambridge University Press.

Sahlender, J. 2020. Homestage: Ein Festival im Wohnzimmer. Ö1, 25 March. https://oe1.orf.at/artikel/669309/Homestage-Ein-Festival-im-Wohnzimmer. Accesssed: 14 Dezember 2020.

Schmidt, L. 1947. Der Liebe Augustin. Sein Lied und seine Legende. In Wiener Geschichtsblätter. Wien: Verein für Geschichte der Stadt Wien 2: 73-78.

Schrenk, J. and Rachbauer, S. 2020. Balkonkonzerte mit Fensterbank-Plätzen. Kurier, 26 April. https://kurier.at/chronik/wien/balkonkonzerte-mit-fensterbankplaetzen/400824503. Accesssed: 14 Dezember 2020. 
sofe. 2020. Staatsoper startet Livestream-Vorstellungen. ORF, 15 March. https://orf.at/stories/3157979/. Accesssed: 9 Dezember 2020.

Trenkler, T. 2002. "Nino, der Corona-Blues-Killer", spielte live von zu Hause aus. Kurier, 21 March. https://kurier.at/kultur/nino-der-corona-blues-killer-spieltelive-von-zu-hause-aus/400788587. Accessed: 14 December 2020.

Weibel, P. 2020. Virus, Viralität, Virtualität: Wie gerade die erste Ferngesellschaft der Menschheitsgeschichte entsteht. NZZ, 20 March.

https://www.nzz.ch/feuilleton/virus-viralitaet-virtualitaet-peter-weibel-ueberdie-erste-ferngesellschaft-in-der-menschheitsgeschichteId.1547579? reduced=true. Accessed: 14 December 2020.

Whitby, W.-

2020a. PLAYING IN. How Did Musicians Feel About Releasing Music and Self Promotion in the Months of Lockdown? Bido Lito - The Voice of Independent Creative Culture on Merseyside, November. https://www.bidolito.co.uk/feature-playing-in-releasing-promotion-2020. Accessed: 15 December 2020. 2020b. PLAYING IN. The First Phase of Research from Bido Lito! and University of Liverpool into Covid's Affects on the Local Music Industry. Bido Lito - The Voice of Independent Creative Culture on Merseyside, September. https://www.bidolito.co.uk/feature-playing-in-2020. Accessed: 15 December 2020.

Wurmitzer, Michael. 2020. Applaus für ... Ernst Molden. Der Standard, 14 April. https://www.derstandard.at/jetzt/livebericht/2000116238563/redcontent/10001 87263/sargnagel-lou-asril-und-coder-standard-corona-stage-startet?ref= live_red_content\&responsive=false. Accessed: 14 December 2020.

\section{Videography}

Ernst Molden (2020) Ernst Molden ft. Karl Molden (Bass): Balkonkonzert am 20. Mai 2020 / Pt. 2 [Online video]. Available from:

https://www.youtube.com/watch?v=uwY45pf-O3k. Accessed 14 December 2020.

\section{Web Sources}

APA 2017. "Der Song deines Lebens" auf Ö3: "I am from Austria" auf Platz 1. OTS, 9 June. https://www.ots.at/presseaussendung/OTS_20170609_OTS0143/der-songdeines-lebens-auf-oe3-i-am-from-austria-auf-platz-1. Accessed: 14 December 2020.

Donauinselfest 2020. https://donauinselfest.at/dif20-sommertour-gehts/. Accessed: 14 December 2020.

Ernst Molden Facebook Artist Page. https://www.facebook.com/ernstmolden.fanzone. Accessed: 14 December 2020.

Homestage Festivals Facebook page, 2020. https://www.facebook.com/homestagefestivals. Accessed: 14 December 2020. 
Voodoo Jürgens Facebook Artist Page, 2020. https://www.facebook.com/Krachmandlorchester/. Accessed: 14 December 2020.

mica - music Austria, 2020a. Statements on the Corona Crisis - How is the Domestic Music Scene? (Part 1). 23 April. Translated from the German original by Julian Schoenfeld. https://www.musicexport.at/statements-on-the-coronacrisis-how-is-the-domestic-music-scene-doing-part-1/. Accessed: 14 December 2020.

mica - music Austria, 2020b. Statements on the Corona Crisis - How is the Domestic Music Scene? (Part 2). 5 May. Translated from the German original by Julian Schoenfeld. https://www.musicexport.at/statements-on-the-coronacrisis-how-is-the-domestic-music-scene-part-two/. Accessed: 14 December 2020.

mica - music Austria, 2020c. Statements on the Corona Crisis - How is the Domestic Music Scene? (Part 3). 19 May. Translated from the German original by Julian Schoenfeld. https://www.musicexport.at/statements-on-the-coronacrisis-how-is-the-domestic-music-scene-doing-part-3/. Accessed: 14 December 2020.

Porgy \& Bess Website, 2020. https://www.porgy.at/en/page/der-club/. Accessed: 09 December 2020.

Raumpioniere Website, 2020. https://www.raumpioniere.at/homestagefestivals. Accessed: 14 December 2020.

Wiener Beschwerdechor Website, 2020.

https://www.wienerbeschwerdechor.at/category/news/. Accessed: 14 December 2020. 